\title{
HUBUNGAN ANTARA ASUPAN ENERGI DENGAN STATUS GIZI BATITA UMUR 1-3 TAHUN DI DESA MOPUSI KECAMATAN BOLAANG MONGONDOW INDUK SULAWESI UTARA 2014
}

\author{
${ }^{1}$ Risa K. F. Sahalessy \\ ${ }^{2}$ Nova H. Kapantow \\ ${ }^{2}$ Nelly Mayulu \\ ${ }^{1}$ Kandidat Skripisi Fakultas Kedokteran Universitas Sam Ratulangi Manado \\ ${ }^{2}$ Staf Bagian Gizi Fakultas Kedokteran Universitas Sam Ratulangi Manado \\ Email: rsahalessy@yahoo.com
}

\begin{abstract}
Nutritional transition is very important to reduce infectious disease prevalence and under nourishment. Whenever we have a balance food intake, our nutrition status will be good. This study aimed to obtain the relation between the energy intake and the nutrition status based on the anthropometric indices: W/A, H/A, W/H, and IMT/A. This was an analytical study with a cross sectional design, using the purposive sampling method. Total samples were 90 children aged under 3 years. Data were collected by using interview about food recall, body weight, and height. The results showed that 62 children (68.9\%) had normal nutritional status by using index IMT/A; good nutrition with W/A in 66 children (73.3\%); H/A normal in 41 children (45.6\%); and W/H normal in 71 children (78.9\%). The Spearman's rank test showed a coefficient value (r) equal to $-0,245$ and p $0.02<\alpha=0.05$. Conclusion: In most of the children aged under 3 years there was a significant relationship between energy intake and nutrition status (W/A).
\end{abstract}

Keywords: energy intake, nutrition status

\begin{abstract}
Abstrak: Transisi gizi sangat penting untuk menurunkan prevalensi penyakit infeksi dan W/Akekurangan gizi. Status gizi dikatakan baik apabila asupan makanan seimbang. Asupan makanan yang melebihi kebutuhan tubuh akan menyebabkan kelebihan berat badan dan penyakit, sebaliknya, asupan makanan yang kurang dapat menyebabkan tubuh menjadi kurus dan rentan terhadap penyakit. Penelitian ini bertujuan untuk mengetahui hubungan antara asupan energi dengan status gizi berdasarkan indeks antropometri $\mathrm{BB} / \mathrm{U}, \mathrm{TB} / \mathrm{U}, \mathrm{BB} / \mathrm{TB}$, dan IMT/U. Penelitian ini menggunakan metode survei analitik dengan pendekatan potong lintang. Sampel diperoleh dengan metode purposive sampling. Jumlah sampel dalam penelitian ini sebanyak 90 batita yang memenuhi kriteria sampel. Pengumpulan data melalui wawancara dengan menggunakan kuesioner food recall, timbangan berat badan, dan alat ukur tinggi badan.. Hasil penelitian menunjukkan bahwa 62 batita (68,9\%) memiliki status gizi IMT/U nomal; 66 batita (73,3\%) BB/U gizi baik; 41 batita (45,6\%) TB/U normal; dan 71 batita $(78,9 \%) \mathrm{BB} / \mathrm{TB}$ normal. Uji satistik Spearman's rank mendapatkan nilai koefisien korelasi (r) sebesar $-0,245$ dan nilai $p 0,02<\alpha=0,05$. Simpulan: Pada sebagian besar batita umur 1-3 tahun terdapat hubungan bermakna antara asupan energi dan status gizi (BB/U).
\end{abstract}

Kata kunci: asupan energi, status gizi

Status gizi adalah keadaan kesehatan akibat interaksi anatara makanan dan faktor-faktor antara lain: keadaan gizi yang mencakup konsumsi makanan dan kesehatan, daya beli keluarga, lingkungan fisik dan sosial, zat gizi dalam makanan, kebiasaan makan dan pemeliharaan kesehatan. ${ }^{1}$ Beban ganda masalah gizi masalah gizi menciptakan 
berbagai persoalan gizi di Indonesia. Kekurangan gizi pada anak dapat menyebabkan pertumbuhan fisik dan otak anak tidak optimal, anak menjadi kurus dan sangat pendek (stunting). Bila hal ini tidak segera diatasi dalam jangka panjang akan mengakibatkan hilangnya potensi generasi muda yang cerdas dan berkualitas (lost generation) sehingga anak menjadi tidak produktif dan tidak mampu bersaing di masa depan. ${ }^{2}$

Penelitian oleh Mananoru tentang hubungan antara asupan energi dengan status gizi pada anak sekolah dasar di Bunaken menjelaskan bahwa status gizi dikatakan baik apabila asupan makanan seimbang, artinya banyak dan jenis makanan yang dimakan sesuai dengan yang dibutuhkan tubuh. Sebaliknya, dikatakan status gizi salah bila yang dimakan kurang dari yang dibutuhkan sehingga tubuh akan kurus dan sakit-sakitan. ${ }^{3}$ Isdaryanti meneliti asupan protein, status gizi dan prestasi belajar anak sekolah di Arjowinangun Pacitan didapatkan hubungan bermakna antara asupan energi dengan prestasi belajar berdasarkan indeks BB/TB. ${ }^{4}$

\section{METODE PENELITIAN}

Metode penelitian yang digunakan yaitu desain analitik dengan rancangan potong lintang. Populasi penelitian ialah 165 batita berumur 1-3 tahun di desa Mopusi. Sampel penelitian berjumlah 90 batita diambil dengan menggunakan metode purposive sampling. Variabel bebas ialah asupan energi dan variabel terikat ialah status gizi. Penelitian ini menggunakan kuesioner, food recall 2 x 24 jam, food model, microtoise, dan timbangan berat badan digital. Setelah didapatkan data konsumsi makanan, dengan bantuan program nutrisurvey di dapatkan jumlah asupan energi. Analisis data menggunakan uji Spearman's rank.

\section{HASIL PENELITIAN}

Berdasarkan jenis kelamin, sampel laki-laki sebanyak 38 batita (42,2\%) dan perempuan sebanyak 52 batita (57,8\%). Berdasarkan umur, batita yang memiliki umur 12-19 bulan sebanyak 42 batita $(46,7 \%)$ serta merupakan distribusi terbanyak. Berdasarkan anak ke berapa, batita yang merupakan anak ke-1 sebanyak 52 batita (57,8\%) serta merupakan distribusi terbanyak. Berdasarkan jumlah keluarga yang tinggal di rumah bersama 34 orang sebanyak 57 batita (63,3\%) serta merupakan distribusi terbanyak.

Berdasarkan umur ibu, responden yang berumur 15-25 tahun sebanyak 64 ibu (71\%) serta merupakan distribusi terbanyak. Berdasarkan pekerjaan ibu, responden yang memeiliki pekerjaan IRT sebanyak 78 ibu (86,7\%) serta merupakan distribusi terbanyak. Berdasarkan latar belakang pendidikan ibu lulusan SD sebanyak 37 orang $(41,1 \%)$ serta merupakan distribusi terbanyak. Berdasarkan penghasilan rata-rata responden yang tidak memiliki penghasilan sebanyak 76 orang $(84,4 \%)$ serta merupakan distribusi terbanyak.

Berdasarkan pekerjaan ayah, yang memiliki pekerjaan petani sebanyak 37 orang $(41,1 \%)$ serta merupakan distribusi terbanyak. Berdasarkan latar belakang pendidikan ayah lulusan SMP sebanyak 39 orang $(43,3 \%)$ serta merupakan distribusi terbanyak. Berdasarkan penghasilan ratarata ayah batita, yang memiliki penghasilan 1-3 juta sebanyak 41 orang $(45,6 \%)$ serta merupakan distribusi terbanyak.

Dari 90 sampel yang diteliti terdapat 87 batita yang memiiliki asupan energi kurang, 3 batita memiliki status gizi cukup.

\section{Gambaran Status Gizi Anak Batita Menurut IMT/U, BB/U, TB/U, BB/TB}

Berdasarkan hasil penelitian didapatkan status gizi indeks massa tubuh berdasarkan umur yang dikategorikan normal sebanyak 62 batita (68,9\%) serta merupakan distribusi terbanyak. Berdasarkan status gizi berat badan menurut umur sebanyak 66 batita (73,3\%) serta merupakan distribusi terbanyak. Berdasarkan status gizi tinggi badan menurut umur yang dikategorikan normal sebanyak 41 batita (45,6\%) serta merupakan distribusi terbanyak. 
Berdasarkan status gizi berat badan menurut tinggi badan yang dikategorikan normal sebanyak 71 batita (78,9\%) serta merupakan distribusi terbanyak.

\section{Hubungan antara asupan energi dengan status gizi}

Berdasarkan uji statistik hubungan status gizi (IMT/U) dengan asupan energi didapatkan nilai koefisien korelasi (r) sebesar $-0,003$ dan nilai $\mathrm{p}=0,978<\alpha=$ 0,05 . Hal ini menunjukkan tidak terdapat hubungan status gizi (IMT/U) dengan asupan energi pada batita umur 1-3 tahun di Desa Mopusi.

Berdasarkan uji statistik hubungan status gizi $(\mathrm{BB} / \mathrm{U})$ dengan asupan energi di dapatkan nilai koefisien korelasi (r) sebesar $-0,245$ dan nilai $p=0,02<\alpha=0,05$. Hal ini menunjukkan bahwa terdapat hubungan status gizi $(\mathrm{BB} / \mathrm{U})$ dengan asupan energi pada batita umur 1-3 tahun di Desa Mopusi.

Berdasarkan hasil uji statistik hubungan status gizi (TB/U) dengan asupan energi di dapatkan nilai koefisien korelasi (r) sebesar $-0,088$ dan nilai $\mathrm{p}=0,407<\alpha=$ 0,05 . Hal ini menunjukkan bahwa tidak terdapat hubungan satus gizi (TB/U) dengan asupan energi pada batita umur 1-3 tahun di Desa Mopusi.

Berdasarkan hasil uji statistik, hubungan status gizi (BB/TB) dengan asupan energi di dapatkan nilai koefisien korelasi (r) sebesar 0,017 dan nilai $\mathrm{p}=$ $0,875<\alpha=0,05$. Hal ini menunjukkan bahwa tidak terdapat hubungan status gizi (BB/TB) dengan asupan energi batita umur 1-3 tahun di Desa Mopusi.

\section{BAHASAN}

Berdasarkan hasil wawancara konsumsi makanan dengan menggunakan food recall 2 x 24 jam yang dilakukan pada ibu batita, di dapatkan 96,7\% batita dengan gizi kurang, 3,3\% batita dengan gizi cukup. Sampel yang termasuk kategori gizi kurang disebabkan karena jenis dan jumlah makanan yang dikonsumsi tidak sesuai kebutuhan. Penelitian oleh Chairunisa mendapatkan status gizi kurang di wilayah kerja puskesmas Bugangan sebesar 42,1\%. Dibandingkan dengan RISKESDAS 2010 yang menunjukkan prevalensi gizi kurang sebesar 13\%, maka anak 1-2 tahun dengan status gizi kurang di wilayah kerja puskesmas Bugangan tergolong tinggi. ${ }^{5}$ Penelitian oleh Djola di Kecamatan Modayag Barat, menyatakan bahwa pendapatan orang tua tidak memengaruhi aspuan dan status gizi anak. ${ }^{6}$ Berbeda dengan penelitian yang dilakukan oleh Purwaningrum dan Wardani di wilayah kerja puskesma Sewon 1 Bantul, menyatakan bahwa pendidikan dan pendapatan responden berpengaruh terhadap asupan makanan (energi) balita. ${ }^{7}$

\section{Asupan energi}

Berdasarkan hasil penelitian didapatkan 96,7\% batita dengan gizi kurang, 3,3\% batita dengan gizi cukup. Pada usia batita diperlukan asupan energi yang cukup untuk pertumbuhan batita. Energi dapat timbul karena adanya pembakaran karbohidrat, lemak dan protein, karena itu agar energi tercukupi perlu pemasukan makanan yang cukup dengan mengkonsumsi makanan yan cukup dan seimbang. ${ }^{8}$

\section{Status Gizi}

Hasil penelitian status gizi berdasarkan IMT/U didapatkan batita dengan status gizi normal sebanyak 62 orang dan merupakan distribusi terbanyak, sedangkan batita dengan status gizi sangat kurus sebanyak 5 orang dan merupakan distribusi terendah.

Hasil penelitian BB/U didapatkan batita dengan status gizi baik sebanyak 66 orangdan merupakan distribusi terbanyak, sedangkan batita dengan status gizi lebih sebanyak 1 orang dan merupakan distribusi terendah.

Hasil penelitian berdasarkan TB/U didapatkan batita dengan status gizi normal sebanyak 41 orang dan merupakan distribusi terbanyak, sedangkan batita dengan tinggi sebanyak 3 orang dan merupakan distribusi terendah.

Berdasarkan BB/TB didapatkan batita dengan status gizi normal sebanyak 71 
orang dan merupakan distribusi terbanyak, sedangkan batita dengan status gizi sangat kurus sebanyak 1 orang dan merupakan distribusi terendah. Bila dibandingkan dengan penelitian yang dilakukan di Amerika pada tahun 2007-2008 dari 3.281 anak-anak dan remaja yang berusia 2-19 tahun, 13,9\% memiliki berat badan lebih, $19,6 \%$ berisiko berat badan lebih dan $34,1 \%$ normal. ${ }^{9}$ Penelitian yang dilakukan oleh Mengistu et al. di Hidabu pada batita usia 6-59 bulan mendapatkan 12,9\% batita jenis kelamin perempuan dan $17,9 \%$ batita dengan jenis kelamin laki-laki memiliki status gizi kurang (underweight). Batita dengan jenis kelamin laki-laki yang sangat pendek (stunting) 25,9\% sedangkan pada batita perempuan 21,7\%. Batita dengan jenis kelamin laki-laki yang pendek (wasting) 9,3\%, sedangkan pada batita perempuan $7,6 \%{ }^{10}$

\section{Hubungan Antara Asupan Energi dengan Status Gizi}

Hasil penelitian yang dilakukan pada batita umur 1-3 tahun di Desa Mopusi dianalisis dengan uji korelasi Spearman's rank dengan nilai signifikansi 0,05. Dari hasil analisis didapatkan hubungan bermakna antara asupan energi dengan status gizi. Hal ini dilihat dari penilaian status gizi berdasarkan indeks BB/U. Tidak terdapat hubungan bermakna antara asupan energi dengan status gizi batita berdasarkan indeks IMT/U, TB/U, dan BB/TB. Berbeda dengan penelitian yang dilakukan oleh Hapsari berdasarkan asupan energi, distribusi status gizi dengan indikator TB/U diperoleh nilai $\mathrm{p}=0,027, \mathrm{p}=\alpha(0,05)$ yang menunjukkan terdapat hubungan antara status gizi TB/U dengan asupan energi. ${ }^{11}$

\section{SIMPULAN}

Dari hasil penelitian di Desa Mopusi Kecamatan Lolayan Kabupaten Bolaang Mongondow Induk dapat disimpulkan bahwa sebagian besar batita umur 1-3 tahun memiliki asupan energi kurang dibawah nilai AKG tetapi berstatus gizi normal. Terdapat hubungan bermakna antara asupan energi dengan status gizi $(\mathrm{BB} / \mathrm{U})$.

\section{SARAN}

1. Mengaktifkn kembali sarana puskesmas di Desa Mopusi.

2. Mengadakan program pemantauan gizi untuk anak batita.

3. Perlu diadakan penyuluhan kepada orang tua tentang pola makan yang benar dan sehat.

\section{DAFTAR PUSTAKA}

1. Supriasa IDN et al. Penilaian Status Gizi Indeks Antropometri. Jakarta: ECG, 2001.

2. Sulistyoningsih H. Gizi Untuk Kesehatan Ibu dan Anak. Yogyakarta: Graha Ilmu, 2011.

3. Mananoru W. Hubungan Antara Asupan Energi Dengan Status Gizi Pada Anak Sekolah Dasar di Kelurahan Bunaken Kecamatan Kepulauan Bunaken Kota Manado Sulawesi Utara [Karya Tulis Program Sarjana]. Manado: Fakultas Kesehatan Masyarakat Universitas Sam Ratulangi, 2013.

4. Isdaryanti C. Asupan Energi Protein, Status Gizi dan Prestasi Belajar Anak Sekolah Dasar Arjowinangun Pacitan [Karya Tulis]. Yogyakarta: Universitas Gadjah Mada, 2007.

5. Nur Rarastiti C. Hubungan Karakteristik Ibu, Frekuensi Kehadiran Anak ke Posyandu, Asupan Energi Protein dengan Status Gizi Anak Usia 1-2 Tahun [Tesis]. Semarang: Universitas Diponegoro, 2013.

6. Djola R. Hubungan Antara Tingkat Pendapatan Keluarga dan Pola Asuh dan Status Gizi Anak Balita Di Desa Bongkudai Kecamatan Modayag Barat [Skripsi]. Manado: Universitas Sam Ratulangi, 2011.

7. Purwaningrum S, Wardani Y. Hubungan Antara Asupan Makanan dan Status Kesadaran Gizi Keluarga dengan Status Gizi Balita di Wilayah Kerja Puskesmas Sewon 1, Bantul. [Skripsi]. Yogyakarta: Universitas Ahmad Dahlan, 2012.

8. Danone Institut Nakita. Sehat dan Bugar Berkat Gizi Seimbang. Jakarta: Kompas Gramedia. 2010. 
9. Ogden CL, Carrol MD, Kit BK, Glegal

KM. Prevalence of childhood and adult obesity in the United States, 20112012. JAMA. 2014;311(8):806-14.

10.Mengistu $K$, Alemu $K$, Destaw $B$. Prevalence of Malnutrition and Associated Factors Among Children Aged 6-59 months at Hidabu Abote District, North Shewa, Oronia Regional
State. J Nutr Disorders Ther. Doi: 10.4172/2161-0509. T1-001.

11.Sulistya H. Hubungan Tingkat Asupan Energi dan Protein Dengan Kejadian Gizi Kurang Anak Usia 2-5 Tahun. [Skripsi]. Semarang: Program studi gizi Universitas Muhammadiyah Semarang, 2013. 